\title{
Development of a nutrient-dense food supplement for HIV-infected women in rural Kenya using qualitative and quantitative research methods
}

\author{
Steven Y Hong ${ }^{1,2, *}$, Kristy M Hendricks ${ }^{3}$, Christine Wanke ${ }^{1,2}$, Gloria Omosa $^{4}$, \\ Shem Patta ${ }^{4}$, Ben Mwero ${ }^{4}$, Innocent Mjomba ${ }^{4}$, Jeanette Queenan ${ }^{1,2}$ and \\ Mkaya Mwamburi ${ }^{2,4}$ \\ 'Division of Geographic Medicine and Infectious Diseases, Tufts Medical Center, Boston, USA: ${ }^{2}$ Department of \\ Public Health and Community Medicine, Tufts University School of Medicine, 150 Harrison Avenue, Jaharis 2, \\ Boston, MA 021 1 1, USA: ${ }^{3}$ Community Health Research Program, Hood Center for Children and Families, \\ Dartmouth Medical School, Lebanon, NH, USA: ${ }^{4}$ Voi Research Centre, Voi, Kenya
}

Submitted 20 September 2011: Final revision received 16 July 2012: Accepted 1 August 2012: First published online 14 September 2012

\begin{abstract}
Objective: Formative research to facilitate the development, packaging and delivery of a culturally acceptable nutrition intervention for HIV-infected women in rural Kenya for an intervention trial.

Design: Focus group discussion on three areas: (i) ingredients and form of the nutrition intervention, (ii) packaging and delivery and (iii) monitoring of adherence. Two single-blind taste tests with eleven different porridge formulations of various combinations of maize flour, soyabeans, peanuts, sorghum, mung beans, dried fish, raisins and dried whole milk. Follow-up acceptability focus group discussion was also conducted.

Setting: Voi, Kenya, community based.

Subjects: Focus group discussion and two taste tests (twenty-one women aged 16-55 years). Follow-up acceptability focus group discussion (four women enrolled in intervention trial).

Results: The preferred porridge for taste consisted of maize, soyabeans and peanuts. For animal protein, dried whole milk and dried fish were used. Although the women disliked the taste of dried fish, it was acceptable if added in small undetectable quantities. Sugar over lime was favoured for taste. Women believed they could consume at least two cups of porridge per day without displacing their usual meals. The optimal delivery interval was believed to be every two weeks in individual serving packages. Women who had been consuming porridge for several weeks felt the taste was acceptable for long-term consumption.

Conclusions: This formative research resulted in the development, packaging and delivery of a nutrient-dense food supplement using local ingredients to meet the dietary needs of the population and acceptable for daily consumption by women in Kenya for evaluation in an intervention trial.
\end{abstract}

Weight loss is associated with progression of HIV disease ${ }^{(1)}$, but it is unclear whether weight loss is a cause of disease progression or a marker for disease severity. There are data suggesting that the use of micronutrients could reduce CD4 count decline and delay death ${ }^{(2-4)}$, however micronutrients alone will not support or maintain nutritional status. Studies have also suggested that there is improved survival in HIV-infected patients who are overweight or obese compared with those who are malnourished ${ }^{(5)}$. One study conducted in women demonstrated that higher baseline BMI was associated with a lower rate of CD4 count falling to below 200 cells/ $\mu$ l. Also, underweight women had an increased risk of death ${ }^{(5)}$. However, no prospective trial to date has demonstrated that progression of HIV can be delayed by the provision of nutritional support ${ }^{(6)}$.

In preparation for a randomized trial to be conducted in rural Kenya to assess whether providing nutritional support can delay the progression of HIV, we conducted formative research to inform the development, packaging and delivery of a culturally acceptable nutrition intervention using qualitative and quantitative research methods. Our group is conducting a dietary intervention to improve nutritional status in HIV-infected women who are early in the course of their infection in the Mwatate, Wundanyi or Voi Districts in Kenya, to delay the progression of HIV disease. Five hundred women with CD4 cell counts 
between 400 and 750 cells/ $\mu$ l will be randomized to receive a nutrient-dense food supplement (NDFS) or to standard of care, and it will be determined whether the use of NDFS reduces the rate of CD 4 decline and delays the need to begin antiretroviral therapy. The women will be followed until the initiation of antiretroviral therapy is necessary or for a total of 2 years.

Our proposed intervention is based on an estimated additional $20 \%$ of daily protein intake above WHO requirements; based on this the NDFS will provide onequarter of estimated daily protein needs. Based on a nutritional assessment we conducted to determine energy and protein consumption of an HIV-negative comparison group, we estimated the total target intake would be $9849 \mathrm{~kJ}(2354 \mathrm{kcal})$ and $59 \mathrm{~g}$ of protein ( $15 \mathrm{~g}$ from NDFS). These ranges are consistent with the Kenyan National Guidelines on Nutrition and HIV/AIDS ${ }^{(7)}$, which recommends a range of $50-80 \mathrm{~g}$ of protein/ $\mathrm{d}$ for most people.

The primary intervention study aimed to develop a food intervention using locally available ingredients for the purpose of sustainability. Therefore, we proposed to use a dietary modification of 'power porridge', a term that is locally known to refer to a maize-based porridge with additional ingredients. Previous formative research including focus group discussions (FGD) and key informant interviews conducted through Kenya Food and Nutrition Technical Assistance (FANTA) ${ }^{(8)}$ revealed that HIV-positive individuals believed 'power porridge' was nutritionally rich and that it was being promoted and widely used throughout the country for people living with HIV/AIDS. Additional nutrition and food security data collected by our group in Wundanyi region on food availability and consumption patterns indicated a relatively low protein intake, low dietary diversity and daily consumption of porridge, which also informed the intervention design ( $M$ Min and M Mwamburi, unpublished results). Using porridge as a basis, we developed recipes including locally available ingredients that would increase the protein and micronutrient density of the food. We calculated the $20 \%$ increase in protein needs and provision of $25 \%$ of this provided by the NDFS. This amount of protein will be provided to participants if they consume two cups of porridge at least four times weekly. One hundred grams of porridge (dry weight) will cook into two cups. Each participant will have sufficient NDFS for daily consumption (two cups/d).

The present study aimed to facilitate the design, packaging and delivery of a culturally acceptable NDFS using local ingredients for HIV-infected women in rural Kenya for an intervention trial.

\section{Methods}

\section{Study design}

We conducted a series of community-based FGD, faceto-face interviewer-administered questionnaires, single-blind taste tests on different formulations of porridge and a follow-up acceptability FGD in patients enrolled in the intervention trial. Ethical approval was obtained from the institutional review board at Tufts University School of Medicine in Boston, USA and the Kenyatta National Hospital in Nairobi, Kenya.

\section{Participants}

Participants were selected randomly from women aged 16-55 years with unknown HIV status who were visiting the District Hospital in Voi, a city in rural Kenya. The age range was selected to correspond with the age range of the primary intervention trial. The first FGD/taste test had ten participants and the second taste test had eleven participants to allow for good discussions. The final FGD involved four HIV-infected women aged 16-55 years who had been receiving NDFS for 3-5 weeks in the intervention trial. The final FGD had only four participants because the goal was to assess acceptability of the food intervention early during the primary intervention trial in case modifications were needed.

\section{Procedures}

The first FGD was conducted for the purpose of gathering information on three primary areas: (i) the ingredients and form of the food, (ii) packaging and transport and (iii) monitoring of adherence. Study investigators and Voi Research Centre staff developed questions that were deemed to be crucial for the success of the primary intervention, which were translated into Swahili, backtranslated to English to ensure accuracy and pre-tested for clarity. The FGD team consisted of a moderator who guided the discussion and probed to answer the guiding questions, and a person to keep detailed notes of the discussion. Discussions were also audio-recorded. All answers were translated into English and back-translated to ensure accuracy.

Two single-blind taste tests were conducted in order to evaluate different formulations of NDFS for taste and acceptability to women living in this region of Kenya. The NDFS was in the form of a porridge prepared by the Voi Research Centre staff. For the first taste test, six different formulations of porridge were given to the women for tasting and rated for taste, sweetness, texture, likeability and overall acceptability. The second taste test had five different porridge formulations. The porridges were prepared on the morning of the taste tests by mixing the pre-set amount of ingredients for each formulation with boiling water for $10 \mathrm{~min}$. Each porridge formulation was given to the participant in a plastic cup to taste in varying orders. Each participant was requested to drink water between each tasting to wash away the taste of the previous porridge. Participants were asked to rate each porridge immediately after tasting. Participants were blinded to the ingredients of each of the formulations they tasted.

The last FGD involved four women who had been receiving NDFS for 3-5 weeks to assess the acceptability 
Table 1 Nutrient content* per $100 \mathrm{~g}$ for ingredients on which porridges were based

\begin{tabular}{|c|c|c|c|c|c|c|c|c|c|c|}
\hline Ingredients & $\begin{array}{c}\text { Energy } \\
(\mathrm{kJ})\end{array}$ & $\begin{array}{l}\text { Energy } \\
\text { (kcal) }\end{array}$ & $\begin{array}{l}\text { Protein } \\
\text { (g) }\end{array}$ & $\begin{array}{l}\% \text { Energy } \\
\text { from protein }\end{array}$ & $\begin{array}{l}\% \text { Energy } \\
\text { from fat }\end{array}$ & $\begin{array}{l}\text { Vitamin A } \\
\text { (IU) }\end{array}$ & $\begin{array}{l}\mathrm{Ca} \\
(\mathrm{mg})\end{array}$ & $\begin{array}{l}\mathrm{Fe} \\
(\mathrm{mg})\end{array}$ & $\begin{array}{l}\mathrm{Zn} \\
(\mathrm{mg})\end{array}$ & $\begin{array}{l}\mathrm{Se} \\
(\mu \mathrm{g})\end{array}$ \\
\hline Maize (dried, raw) & 1515 & 362 & $8 \cdot 1$ & $9 \cdot 0$ & $9 \cdot 0$ & 0 & 6 & $3 \cdot 5$ & $1 \cdot 8$ & $15 \cdot 4$ \\
\hline Soya flour (full-fat) & 1824 & 436 & $34 \cdot 5$ & $27 \cdot 5$ & $39 \cdot 6$ & 120 & 206 & $6 \cdot 4$ & $3 \cdot 9$ & $7 \cdot 5$ \\
\hline Mung beans (dry) & 485 & 116 & $7 \cdot 7$ & $26 \cdot 6$ & 3.9 & 7 & 24 & $2 \cdot 5$ & $1 \cdot 3$ & 0.0 \\
\hline Sorghum & 1418 & 339 & $11 \cdot 3$ & $13 \cdot 3$ & $8 \cdot 8$ & 20 & 15 & $4 \cdot 1$ & $0 \cdot 8$ & $12 \cdot 9$ \\
\hline Raisins & 1251 & 299 & $3 \cdot 1$ & $3 \cdot 5$ & $1 \cdot 3$ & 0 & 50 & $1 \cdot 9$ & $0 \cdot 2$ & 0.6 \\
\hline Sugar & 1619 & 387 & 0.0 & $0 \cdot 0$ & $0 \cdot 0$ & 0 & 1 & $0 \cdot 0$ & $0 \cdot 0$ & $0 \cdot 6$ \\
\hline Milk powder (full-cream) & 2075 & 496 & $26 \cdot 3$ & $21 \cdot 2$ & $48 \cdot 4$ & 1357 & 851 & $0 \cdot 7$ & $3 \cdot 0$ & $29 \cdot 6$ \\
\hline Vegetable oil & 3699 & 884 & $0 \cdot 0$ & 0.0 & $100 \cdot 0$ & 0 & 0 & $0 \cdot 1$ & $0 \cdot 0$ & $45 \cdot 8$ \\
\hline Peanuts & 2372 & 567 & $25 \cdot 8$ & $15 \cdot 8$ & $72 \cdot 7$ & 0 & 92 & $4 \cdot 6$ & $3 \cdot 3$ & $7 \cdot 2$ \\
\hline Fish (small, dried, freshwater) & 1402 & 335 & $58 \cdot 6$ & $69 \cdot 9$ & $25 \cdot 3$ & 271 & 1699 & $2 \cdot 5$ & $5 \cdot 2$ & $100 \cdot 9$ \\
\hline
\end{tabular}

*Nutrient values taken from the Tanzania Food Composition Tables, $2008^{(9)}$. If nutrient values were unavailable in the Tanzania Food Composition Tables, then they were imputed from the Nutrition Data System for Research (NDSR) software version 2009, developed by the Nutrition Coordinating Center, University of Minnesota, Minneapolis, MN, USA.

of taste, packaging, method of delivery, storage and adherence monitoring. The final FGD was conducted similarly to the first FGD. Questions were developed and refined by the study investigators and Voi Research Centre staff, translated into Swahili, back-translated to ensure accuracy and pre-tested for clarity.

\section{Analysis of focus group discussions}

For the FGD we derived observable patterns or themes that were based on the three primary areas: (i) the ingredients and form of the food, (ii) packaging and transport of the supplement and (iii) monitoring of adherence. Domains were identified and used to form a hierarchical structure of observable concepts. FGD transcripts were analysed using a thematic approach and domain analysis.

\section{Formulations of nutrient-dense food supplement}

Using locally available foods identified in the FGD, recipes for various formulations of porridge were developed that met the nutrient requirements of the intervention for energy and macronutrients. We attempted to optimize the nutrient density of the intervention by including where possible ingredients that were rich in the key micronutrients for HIV outcomes: Fe, Ca, Zn, vitamins $\mathrm{A}$ and $\mathrm{C}$, and $\mathrm{Se}^{(4)}$ (Table 1). Various combinations of whole maize flour, roasted and ground soyabeans, roasted and ground peanuts, ground sorghum, ground mung beans and dried whole milk were used for the first taste test (Porridges 1-6; Table 2). In addition to ingredients identified by the FGD, we used dried fish because it is a good source of protein, Ca and vitamin $\mathrm{D}$, and because it had been identified as used in 'power porridge' in previous formative research (FANTA) ${ }^{(9)}$. In the second taste test (Porridges 1a-3a; Table 2), utilizing the preferred recipe for taste from Porridges 1-6, we attempted to modify the amount of dried fish to determine how much was acceptable for taste, while still keeping the nutrient value. For Porridges $4 \mathrm{a}$ and $5 \mathrm{a}$ (Table 2), since dried fruits are eaten throughout Africa, we attempted to increase the micronutrient content (vitamins $\mathrm{A}$ and $\mathrm{C}$ specifically) of the intervention by adding raisins to the porridge.

\section{Nutritional composition}

The nutritional composition of the various porridges (Table 2) was calculated using the Tanzania Food Composition Tables ${ }^{(9)}$ and Nutrition Data System for Research (NDSR) software version 2009, developed by the Nutrition Coordinating Center, University of Minnesota, Minneapolis, MN, USA. The Tanzania Food Composition Tables were the primary nutrient data source. If a nutrient value was unavailable in the Tanzania Food Composition Tables, we followed the method of Merchant and Dehghan to select the food from NDSR that most closely matched the local food and the nutrient data imputed from NDSR were added to the food profile ${ }^{(10)}$.

\section{Results}

\section{Form of food}

In the first FGD, women were asked what form of a food would be preferred if they were given a food supplement to consume daily. Most women stated that they preferred a porridge made out of whole maize flour or fermented maize flour. They preferred the flour form so that the supplement could be easily prepared at home. A minority of women stated that they would like a form of food that was ready to consume, which could be carried around.

\section{'Power porridge'}

The women were asked whether or not they were familiar with the term 'power porridge'. All women answered that it was a porridge made out of whole maize, wheat or sorghum, mixed with various ingredients such as milk, ground sardines, dried cassava, peanuts, soyabeans, dried kales, mixed with lime juice and sugar to taste. Their general opinion about 'power porridge' was that it was very nutritious and tasty, especially when sugar, milk or lime was added.

\section{Ingredients}

The women were asked if they were to make a nutrientrich and tasty porridge, what ingredients they would use. 
Table 2 Porridge ingredients and nutritional composition* per $100 \mathrm{~g}$ of porridge

\begin{tabular}{|c|c|c|c|c|c|c|c|c|c|c|c|c|}
\hline Porridge & Ingredients & g & $\begin{array}{l}\text { Energy } \\
(\mathrm{kJ})\end{array}$ & $\begin{array}{l}\text { Energy } \\
\text { (kcal) }\end{array}$ & $\begin{array}{l}\text { Protein } \\
\text { (g) }\end{array}$ & $\begin{array}{l}\% \text { Energy from } \\
\text { protein }\end{array}$ & $\begin{array}{l}\% \text { Energy } \\
\text { from fat }\end{array}$ & $\begin{array}{l}\text { Vitamin A } \\
\text { (IU) }\end{array}$ & $\begin{array}{c}\mathrm{Ca} \\
(\mathrm{mg})\end{array}$ & $\begin{array}{c}\mathrm{Fe} \\
(\mathrm{mg})\end{array}$ & $\begin{array}{l}\mathrm{Zn} \\
(\mathrm{mg})\end{array}$ & $\begin{array}{l}\mathrm{Se} \\
(\mu \mathrm{g})\end{array}$ \\
\hline Porridge 1 & $\begin{array}{l}\text { Maize } \\
\text { Soyabeans } \\
\text { Peanuts } \\
\text { Sugar } \\
\text { Vegetable oil } \\
\text { Milk powder }\end{array}$ & $\begin{array}{r}26 \cdot 0 \\
26 \cdot 0 \\
13 \cdot 0 \\
13 \cdot 0 \\
9 \cdot 0 \\
13 \cdot 0\end{array}$ & 1983 & 474 & 18 & 14 & 46 & 208 & 178 & $3 \cdot 3$ & $2 \cdot 3$ & $14 \cdot 8$ \\
\hline Porridge 2 & $\begin{array}{l}\text { Maize } \\
\text { Soyabeans } \\
\text { Peanuts } \\
\text { Sugar } \\
\text { Vegetable oil } \\
\text { Dried fish }\end{array}$ & $\begin{array}{r}26 \cdot 0 \\
26 \cdot 0 \\
13 \cdot 0 \\
13 \cdot 0 \\
9 \cdot 0 \\
13 \cdot 0\end{array}$ & 1895 & 453 & 22 & 18 & 43 & 67 & 289 & $3 \cdot 5$ & $2 \cdot 6$ & $24 \cdot 1$ \\
\hline Porridge 3 & $\begin{array}{l}\text { Maize } \\
\text { Soyabeans } \\
\text { Mung beans } \\
\text { Sugar } \\
\text { Vegetable oil } \\
\text { Milk powder }\end{array}$ & $\begin{array}{r}26 \cdot 0 \\
26 \cdot 0 \\
13 \cdot 0 \\
13 \cdot 0 \\
9 \cdot 0 \\
15 \cdot 5\end{array}$ & 1736 & 415 & 16 & 14 & 39 & 209 & 170 & $3 \cdot 0$ & $2 \cdot 0$ & $13 \cdot 9$ \\
\hline Porridge 4 & $\begin{array}{l}\text { Maize } \\
\text { Soyabeans } \\
\text { Mung beans } \\
\text { Sugar } \\
\text { Vegetable oil } \\
\text { Dried fish }\end{array}$ & $\begin{array}{r}26 \cdot 0 \\
26 \cdot 0 \\
13 \cdot 0 \\
13 \cdot 0 \\
9 \cdot 0 \\
13 \cdot 0\end{array}$ & 1648 & 394 & 20 & 19 & 36 & 68 & 280 & $3 \cdot 2$ & $2 \cdot 3$ & $23 \cdot 2$ \\
\hline Porridge 5 & $\begin{array}{l}\text { Sorghum } \\
\text { Soyabeans } \\
\text { Peanuts } \\
\text { Sugar } \\
\text { Vegetable oil } \\
\text { Milk powder }\end{array}$ & $\begin{array}{r}26 \cdot 0 \\
26 \cdot 0 \\
13 \cdot 0 \\
13 \cdot 0 \\
9 \cdot 0 \\
13 \cdot 0\end{array}$ & 1958 & 468 & 19 & 15 & 46 & 213 & 181 & $3 \cdot 4$ & $2 \cdot 0$ & $14 \cdot 2$ \\
\hline Porridge 6 & $\begin{array}{l}\text { Sorghum } \\
\text { Soyabeans } \\
\text { Peanuts } \\
\text { Sugar } \\
\text { Oil } \\
\text { Dried fish }\end{array}$ & $\begin{array}{r}26 \cdot 0 \\
26 \cdot 0 \\
13 \cdot 0 \\
13 \cdot 0 \\
9 \cdot 0 \\
13 \cdot 0\end{array}$ & 1870 & 447 & 23 & 19 & 44 & 72 & 291 & $3 \cdot 7$ & $2 \cdot 3$ & $97 \cdot 2$ \\
\hline Porridge 1a & $\begin{array}{l}\text { Maize } \\
\text { Soyabeans } \\
\text { Peanuts } \\
\text { Milk powder } \\
\text { Sugar }\end{array}$ & $\begin{array}{l}22 \cdot 2 \\
22 \cdot 2 \\
22 \cdot 2 \\
22 \cdot 2 \\
11 \cdot 1\end{array}$ & 1912 & 457 & 21 & 17 & 42 & 328 & 257 & $3 \cdot 4$ & $2 \cdot 7$ & $13 \cdot 3$ \\
\hline Porridge $2 a$ & $\begin{array}{l}\text { Maize } \\
\text { Soyabeans } \\
\text { Peanuts } \\
\text { Milk powder } \\
\text { Sugar } \\
\text { Dried fish }\end{array}$ & $\begin{array}{r}22 \cdot 0 \\
22 \cdot 0 \\
22 \cdot 0 \\
22 \cdot 0 \\
11 \cdot 0 \\
1 \cdot 5\end{array}$ & 1904 & 455 & 22 & 18 & 42 & 327 & 278 & $3 \cdot 4$ & $2 \cdot 7$ & $14 \cdot 6$ \\
\hline
\end{tabular}


Table 2 Continued

\begin{tabular}{|c|c|c|c|c|c|c|c|c|c|c|c|c|}
\hline Porridge & Ingredients & $g$ & $\begin{array}{c}\text { Energy } \\
(\mathrm{kJ})\end{array}$ & $\begin{array}{c}\text { Energy } \\
\text { (kcal) }\end{array}$ & $\begin{array}{l}\text { Protein } \\
\text { (g) }\end{array}$ & $\begin{array}{l}\text { \% Energy from } \\
\text { protein }\end{array}$ & $\begin{array}{l}\text { \% Energy } \\
\text { from fat }\end{array}$ & $\begin{array}{l}\text { Vitamin A } \\
\text { (IU) }\end{array}$ & $\begin{array}{c}\mathrm{Ca} \\
(\mathrm{mg})\end{array}$ & $\begin{array}{l}\mathrm{Fe} \\
(\mathrm{mg})\end{array}$ & $\begin{array}{c}\mathrm{Zn} \\
(\mathrm{mg})\end{array}$ & $\begin{array}{l}\mathrm{Se} \\
(\mu \mathrm{g})\end{array}$ \\
\hline Porridge $3 a$ & $\begin{array}{l}\text { Maize } \\
\text { Soyabeans } \\
\text { Peanuts } \\
\text { Milk powder } \\
\text { Sugar } \\
\text { Dried fish }\end{array}$ & $\begin{array}{r}22 \cdot 0 \\
22 \cdot 0 \\
22 \cdot 0 \\
22 \cdot 0 \\
11 \cdot 0 \\
1 \cdot 0\end{array}$ & 1908 & 456 & 21 & 17 & 42 & 328 & 267 & $3 \cdot 4$ & $2 \cdot 7$ & $14 \cdot 0$ \\
\hline Porridge $4 a$ & $\begin{array}{l}\text { Maize } \\
\text { Soyabeans } \\
\text { Peanuts } \\
\text { Milk powder } \\
\text { Dried fish } \\
\text { Dark raisin }\end{array}$ & $\begin{array}{r}22 \cdot 5 \\
22 \cdot 5 \\
22 \cdot 5 \\
22 \cdot 5 \\
1 \cdot 0 \\
9 \cdot 0\end{array}$ & 1879 & 449 & 22 & 18 & $43 \cdot 3$ & 335 & 278 & $3 \cdot 6$ & $2 \cdot 8$ & $14 \cdot 3$ \\
\hline Porridge $5 a$ & $\begin{array}{l}\text { Maize } \\
\text { Soyabeans } \\
\text { Peanuts } \\
\text { Milk powder } \\
\text { Dried fish } \\
\text { Golden raisins }\end{array}$ & $\begin{array}{r}22 \cdot 5 \\
22 \cdot 5 \\
22 \cdot 5 \\
22 \cdot 5 \\
1 \cdot 0 \\
9 \cdot 0\end{array}$ & 1879 & 449 & 22 & 18 & 43 & 335 & 278 & $3 \cdot 6$ & $2 \cdot 8$ & $14 \cdot 3$ \\
\hline $\begin{array}{l}\text { Porridge } 3 a \\
\text { (used in primary intervention) }\end{array}$ & $\begin{array}{l}\text { Maize } \\
\text { Soyabeans } \\
\text { Peanuts } \\
\text { Sugar } \\
\text { Dried fish } \\
\text { Milk powder }\end{array}$ & $\begin{array}{r}23 \cdot 9 \\
23 \cdot 9 \\
17 \cdot 9 \\
17 \cdot 9 \\
1 \cdot 5 \\
14 \cdot 9\end{array}$ & 1841 & 440 & $19 \cdot 6$ & 16 & 36 & 235 & 220 & $3 \cdot 3$ & $2 \cdot 5$ & $12 \cdot 8$ \\
\hline
\end{tabular}

${ }^{*}$ Nutrient values were taken from the Tanzania Food Composition Tables, $2008^{(9)}$. If nutrient values were unavailable in the Tanzania Food Composition Tables, then they were imputed from the Nutrition Data System for Research (NDSR) software version 2009, developed by the Nutrition Coordinating Center, University of Minnesota, Minneapolis, MN, USA. 
Table 3 Taste test results

\begin{tabular}{|c|c|c|c|c|c|c|c|}
\hline & Good (\%) & Fair (\%) & $\operatorname{Bad}(\%)$ & Like (\%) & Would eat (\%) & Favourite (\%) & Least favourite (\%) \\
\hline \multicolumn{8}{|c|}{ Taste test $1(n 10)$} \\
\hline Porridge 1 & 100 & 0 & 0 & 100 & 100 & 90 & 0 \\
\hline Porridge 2 & 30 & 40 & 30 & 30 & 20 & 0 & 10 \\
\hline Porridge 3 & 60 & 40 & 0 & 80 & 80 & 10 & 20 \\
\hline Porridge 4 & 20 & 60 & 20 & 20 & 30 & 0 & 20 \\
\hline Porridge 5 & 80 & 20 & 0 & 80 & 80 & 0 & 0 \\
\hline Porridge 6 & 20 & 60 & 20 & 20 & 30 & 0 & 50 \\
\hline \multicolumn{8}{|c|}{ Taste test $2(n 11)$} \\
\hline Porridge 1a & 91 & 9 & 0 & 91 & 82 & 82 & 0 \\
\hline Porridge $2 \mathrm{a}$ & 27 & 36 & 36 & 55 & 60 & 9 & 9 \\
\hline Porridge $3 a$ & 91 & 9 & 0 & 73 & 82 & 9 & 0 \\
\hline Porridge $4 a$ & 64 & 27 & 9 & 64 & 73 & 0 & 64 \\
\hline Porridge 5a & 60 & 30 & 10 & 50 & 60 & 0 & 27 \\
\hline
\end{tabular}

Most women answered that they would use peanuts, soyabeans, cassava, avocado, pumpkin, lime juice, maize flour, sugar or milk. Milk, soyabeans and eggs were chosen for their protein; cassava and maize for carbohydrates; avocado for fats; and pumpkins, kales and lime juice for vitamins.

\section{Consumption}

When asked how many cups of porridge they could consume per day, 4/21 (19\%) stated one cup, 8/21 (38\%) stated two cups, 5/21 (24\%) stated three cups and 4/21 (19\%) stated more than three cups. All women (21/21, $100 \%)$ preferred to record their own consumption of NDFS daily rather than being asked at the end of two weeks. Some women suggested that they should be provided with a timetable to mark once they consumed the supplement. Sixteen of the twenty-one women (76\%) stated that the porridge would supplement their usual meals, while $5 / 21(24 \%)$ stated that the porridge would replace one of their usual meals. All of the women (21/21, 100\%) stated that they would share the porridge with family members.

\section{Packaging, delivery and storage}

A majority of women (14/21, 67\%) were in agreement that NDFS deliveries should be conducted every two weeks instead of every four weeks. They also would rather have the food individually packaged as a single daily portion instead of in bulk (12/21, 57\%). All of the women $(21 / 21,100 \%)$ had the required equipment to prepare the porridge at home, and in order to store the food supplement at home, they stated that they would need the use of a bucket with a lid.

\section{Taste tests}

Taste test 1 had six different formulations of porridge and taste test 2 had five. The ingredients and nutritional compositions are listed in Table 2. For taste test 1 (Table 3), Porridge 1 , which contained maize flour, soyabeans, peanuts, dried milk, sugar and oil, was the favourite of $90 \%$ of the women, rated as 'good' for taste by $100 \%$, liked by $100 \%$ and $100 \%$ said they would eat it every day. Porridge 3 , containing maize, soyabeans, mung beans, dried milk, sugar and oil, was the favourite of $10 \%$ of the women, rated as 'good' for taste by $60 \%$, liked by $80 \%$ and $80 \%$ said they would eat it every day. Porridge 5, containing sorghum, soyabeans, peanuts, dried milk, sugar and oil, was not listed as a favourite, was rated as 'good' for taste by $80 \%$, liked by $80 \%$ and $80 \%$ said they would eat it every day. Porridges 2 , 4 and 6, containing dried fish, had less favourable results in all categories of taste compared with porridges without dried fish (Table 3).

For taste test 2 (Table 3), Porridge 1a, containing maize flour, soyabeans, peanuts, dried milk and sugar, was the favourite of $82 \%$ of the women, rated as 'good' for taste by $91 \%$, liked by $91 \%$ and $82 \%$ said they would eat it every day. Porridge $3 \mathrm{a}$, containing maize flour, soyabeans, peanuts, dried milk, sugar and $1.0 \mathrm{~g}$ of dried fish, was the favourite of $9 \%$ of the women, rated as 'good' for taste by $91 \%$, liked by $73 \%$ and $82 \%$ said they would eat it every day. Porridge $2 \mathrm{a}$, containing maize flour, soyabeans, peanuts, dried milk, sugar and $1.5 \mathrm{~g}$ of dried fish, was the favourite of $9 \%$ of the women, was rated as 'good' for taste by $27 \%$, liked by $55 \%$ and $60 \%$ said they would eat it every day. Porridges $4 \mathrm{a}$ and $5 \mathrm{a}$ containing two different types of raisins had less favourable results in all categories of taste compared with porridges without raisins (Table 3).

\section{Follow-up acceptability focus group discussion}

After receiving several weeks of NDFS (modified Porridge $3 \mathrm{a}$ ), the women in the follow-up acceptability FGD felt that the taste of the porridge was acceptable to them for long-term consumption. The women were divided in their opinion on whether or not to have the NDFS delivered to their home, at another designated location, or to pick it up at the clinic. It was believed by one woman that since the delivery people were in unmarked clothing and vehicles, there was no issue with any level of disclosure of HIV status. However, other women believed that a regular delivery person may raise questions from their neighbours. It was also suggested that the delivery person be a female or a male/female team to avoid suspicion. The method and size of the packaging of the NDFS was found to be acceptable. There was a concern about the need for a plastic container 
issued to the patients for storage specifically for the NDFS to minimize contamination and protection from pests. The women felt that the amount of NDFS they received was adequate for sharing with their family and their personal consumption. However, they expressed that it was possible NDFS could displace their usual meals. The preparation of the porridge took approximately $10 \mathrm{~min}$ and did not pose any difficulties. The daily recording of NDFS consumption in logbooks was not a difficult task for the women.

\section{Discussion}

In order to design a culturally appropriate and acceptable nutrition intervention for HIV-infected women in rural Kenya, formative research was conducted, including FGD, face-to-face interviewer-administered questionnaires, single-blind taste tests on different formulations of 'power porridge', a consumption survey and a follow-up acceptability FGD. Although previous formative research in Kenya $^{(8)}$ demonstrated 'power porridge' was being used as nutrition supplementation among HIV-infected patients, there was lack of data on its optimal formulation and acceptability, the best way to package and transport the supplement, and the best way to monitor consumption.

Although FGD and taste test studies have been conducted to design acceptable formulations of various food products $^{(11-17)}$, there are few studies documenting this type of formative research with the purpose of designing a food for an intervention trial. One such study ${ }^{(18)}$ was conducted in South Africa to assess consumer acceptability of an instant soya-maize porridge compared with an instant plain maize porridge for use in an HIV nutrition intervention trial. Overall, consumers found the soya-maize porridge more acceptable than the plain maize porridge. The study authors emphasized the need for sensory evaluation of food products prior to including them in intervention studies.

Another formative research study was conducted to inform the design of a clinical trial in Lilongwe, Malawi on the safety and efficacy of antiretroviral therapy and nutrition interventions to reduce postnatal transmission of HIV. Semi-structured interviews, FGD, home observations and taste trials were conducted. The women preferred the maize-soya blend and the sweet biscuit. Due to difficulties in product supply, an additional taste test of a nutritionally fortified peanut butter paste was conducted with seventeen women, and this product was also found to be acceptable. As a result, the protocol was modified to achieve cultural acceptability. The study authors stated that without the formative research the implementation of the trial would have been jeopardized. They also emphasized that researchers who conduct clinical trials should incorporate formative research into their protocol design to ensure participant understanding of the research, to safeguard participants, and to increase feasibility and acceptance of the clinical research in the community ${ }^{(19)}$.
In the present study, initial FGD revealed that a 'power porridge' consisting of locally available ingredients was a culturally acceptable form of nutrition supplementation in rural Kenya. Previous studies in different Sub-Saharan African settings showed that various combinations of locally available ingredients were acceptable for consumption $^{(11-17)}$. Our taste tests revealed that a porridge consisting of maize, soyabeans and peanuts was preferred over maize, soyabeans and mung beans, or sorghum, soyabeans and peanuts. In addition, the semi-liquid consistency of porridge was acceptable to the women for taste.

Studies have shown that supplementation of micronutrients of varying composition are of health benefit in HIV-infected persons ${ }^{(2,3,20-25)}$. However, an adequate micronutrient intake may be difficult to realize when a large percentage of energy is coming from a grain-based staple food. In order to increase the micronutrients of the porridge, we attempted to replace sugar with raisins for sweetening. However, women did not prefer the taste of the porridges with the addition of raisins. Therefore, fortification of the porridge with a micronutrient powder (Sprinkles $\left.^{\mathrm{TM}}\right)^{(26)}$ was considered, but it was decided not to utilize it for this trial; some method of micronutrient fortification could be considered in a future intervention. Instead, an alternative source of micronutrients was determined to be animal protein such as milk or dried fish. Animal protein was deemed to add a significant nutritional benefit as most animal protein is high in Fe and $\mathrm{Zn}, \mathrm{Ca}$ and vitamin $D$. Therefore, the addition of animal protein to the porridge was considered a high priority.

The first taste test evaluated the addition of animal protein to the porridge formulations with either whole milk powder or dried anchovies. Overwhelmingly, women did not prefer the porridges with dried fish, but preferred the addition of whole dried milk. Nevertheless, since dried fish has higher protein content than dried milk and added important micronutrients such as vitamin A, Ca, Fe, Zn and Se, high priority was placed on finding a formulation which included dried fish that was acceptable to the participants for taste. Therefore, the second taste test was designed to determine whether dried fish could be added in smaller amounts to be undetectable, while preserving the nutritional benefits. Although the porridge excluding dried fish again performed the best in the taste test, the porridge with only one gram of dried fish added per $99 \mathrm{~g}$ of porridge mix (Porridge 3a) did comparably well for taste. Only two women out of the eleven in this taste test detected the fish in this porridge.

Although the nutrient content of Porridge 3a (with dried fish) was similar to that of Porridge 1a (without dried fish; Table 2), we felt the addition of even small amounts of dried fish would be beneficial in providing a complete protein source. Therefore a modified version of Porridge $3 \mathrm{a}$ was used in the primary intervention trial including the following ingredients in these proportions: whole maize flour $16 \mathrm{~kg}$, roasted and ground soyabeans 
$16 \mathrm{~kg}$, roasted and ground peanuts $12 \mathrm{~kg}$, dried whole milk $10 \mathrm{~kg}$, sugar $12 \mathrm{~kg}$, dried anchovies $1 \mathrm{~kg}$. Ratios of the ingredients were modified slightly from Porridge $3 \mathrm{a}$ for ease of measurements and cost (Table 2).

The porridge used in the primary intervention trial (modified Porridge 3a) is produced with locally acquired ingredients, ground to flour, and mixed. The cost of this porridge is $\$ \mathrm{US} 1 \cdot 80 / \mathrm{kg}$. The study requires $100 \mathrm{~g}$ of porridge to be consumed four times per week. Therefore, the cost per person is approximately $\$$ US $2 \cdot 88 /$ month. To prepare the porridge, participants are asked to mix the packet of dry ingredients with two cups of boiling water and cook for $10 \mathrm{~min}$ (stirring constantly) until ready.

FGD revealed that women preferred to have NDFS packaged in daily portions as opposed to bulk because measured packages allowed for easier preparation. Therefore, for the primary intervention, the NDFS was vacuum sealed in $100 \mathrm{~g}$ packets. Within the vacuum-sealed packets, the shelf-life is approximately 1 year.

FGD revealed that the women believed they could easily consume two or more cups per day, most stating that they could consume more than fourteen cups per week. Since the study requirements would be met if women consumed two cups only four times weekly (total eight cups/week), we believed that most women would be able to consume enough porridge for the primary intervention.

FGD revealed that the women would share the NDFS with family members and therefore would need an adequate supply for the whole family. Similarly, in a study in Malawi ${ }^{(19)}$, 53\% of HIV-positive mothers given food supplementation shared it with their neighbours, family members and/or children. Of those who did not share the supplement, $38 \%$ said it would be very difficult not to share it in the future because, as told by one mother, '[in our culture], food has to be shared, no matter how small it is'. In order to possibly reduce sharing, the supplement was named 'Nutrition for Breastfeeding Mothers', and all families were provided with a small bag of maize from the study. Similarly, in our primary intervention study, we provided extra porridge based on the number of people in the household.

The follow-up acceptability FGD revealed that the formulation of NDFS was acceptable for long-term consumption. There was a difference of opinion on whether or not the NDFS should be delivered to the participants' homes due to the concern for HIV status disclosure. Therefore, it was decided that the NDFS delivery would be conducted according to the client's wish, i.e. at the clinic, home or any other designated place.

The strength of the present study is that it used qualitative research method of FGD, which included an ability to undergo in-depth discussion of the important issues, understanding of reasons behind choices and the ability to clarify responses, probing for additional information. Participants were able to actually taste the porridge and give real-time feedback. Also, group dynamics were incorporated to enable further discussion around varying opinions shared.

Some limitations of our methodology included the relatively small sample size and inclusion of only women, which may not be representative of the population. This limitation is inherent in FGD designs, but the aim of the study was to obtain in-depth information from a smaller number of people. Also, participants were chosen to be appropriate for the primary intervention study and not meant to be generalizable to the population of HIV-infected patients in rural Kenya.

\section{Conclusions}

FGD conducted among women in rural Kenya identified 'power porridge' as a culturally acceptable form of a nutrition intervention and identified optimal and culturally sensitive ways to package and deliver the porridge. Taste tests of potential formulations of porridge resulted in the identification of an optimal NDFS that would be acceptable for daily consumption by women in Kenya for evaluation in an intervention trial. In designing clinical trials, formative research is critical to ensure feasibility and acceptability within the community.

\section{Acknowledgements}

Sources of funding: The present study was supported by the National Institutes of Allergy and Infectious Diseases (grants 1R01 HD 057613-01 and P30 AI 42853). S.Y.H. was supported by the National Institute of Allergy and Infectious Diseases (grants 1K23AI097010-01A1, T32 AI007438-16 and L30 AI080268-02). Conflicts of interest: The authors have no conflict of interest to declare. Authors' contribution: S.Y.H. recruited the volunteers, collected the data, performed the analysis and wrote the manuscript. K.M.H. contributed in study conception, study design, obtaining of funding, nutritional analyses and writing of the manuscript. C.W. contributed in study conception, study design, obtaining of funding, supervision of all steps in the study and writing of the manuscript. G.O., S.P., B.M. and I.M. contributed in recruiting of volunteers, collection of data and writing of the manuscript. J.Q. contributed in food calculations and writing of the manuscript. M.M. contributed in study conception, study design, obtaining of funding, supervision of all steps in the study and writing of the manuscript. Acknowledgements: The authors acknowledge the efforts and contributions by Prachie Narain, Daria Thompson, Emily Kituri and the Voi Research Centre staff.

\section{References}

1. Wheeler DA, Gibert CL, Launer CA et al. (1998) Weight loss as a predictor of survival and disease progression in HIV 
infection. Terry Beirn Community Programs for Clinical Research on AIDS. J Acquir Immune Defic Syndr Hum Retrovirol 18, 80-85.

2. Fawzi WW, Msamanga GI, Spiegelman D et al. (2004) A randomized trial of multivitamin supplements and HIV disease progression and mortality. N Engl J Med 351, 23-32.

3. Kaiser JD, Campa AM, Ondercin JP et al. (2006) Micronutrient supplementation increases CD4 count in HIVinfected individuals on highly active antiretroviral therapy: a prospective, double-blinded, placebo-controlled trial. J Acquir Immune Defic Syndr 42, 523-528.

4. Jones CY, Tang AM, Forrester JE et al. (2006) Micronutrient levels and HIV disease status in HIV-infected patients on highly active antiretroviral therapy in the Nutrition for Healthy Living cohort. J Acquir Immune Defic Syndr 43, 475-482.

5. Saghayam S, Kumarasamy N, Cecelia AJ et al. (2007) Weight and body shape changes in a treatment-naive population after 6 months of nevirapine-based generic highly active antiretroviral therapy in South India. Clin Infect Dis 44, 295-300.

6. Swaminathan S, Padmapriyadarsini C, Yoojin L et al. (2010) Nutritional supplementation in HIV-infected individuals in South India: a prospective interventional study. Clin Infect Dis 51, 51-57.

7. Republic of Kenya Ministry of Health (2006) Kenyan National Guidelines on Nutrition and HIV/AIDS. Nairobi: National AIDS and STI Control Programme (NASCOP), available at http://www.fantaproject.org/publications/kenyan_ guidelines2006.shtml

8. Thuita FM (2005) Food and Nutrition Implications of Antiretroviral Therapy in Kenya: A Formative Assessment. Washington, DC: Food and Nutrition Technical Assistance Project (FANTA), Academy for Educational Development, available at http://www.fantaproject.org/downloads/pdfs/ Kenya_ART_Assessment_2005.pdf

9. Lukmanji Z, Hartzmark E, Mlingi N et al. (2008) Tanzania Food Composition Tables, 1st ed. Dar es Salaam \& Boston, MA: Muhimbili University College of Health and Allied Sciences, Tanzania Food and Nutrition Center \& Harvard School of Public Health; available at http://harvardschoolofpublichealth. $\mathrm{com} /$ nutritionsource/files/tanzania-food-composition-tables.pdf

10. Merchant AT \& Dehghan M (2006) Food composition database development for between country comparisons. Nutr J 5, 2 .

11. Bangu NT, Mtebe K \& Nzallawahe TS (1994) Consumer acceptability of stiff porridge based on various composite flour proportions of sorghum, maize and cassava. Plant Foods Hum Nutr 46, 299-303.

12. Owino VO, Irena AH, Dibari F et al. (2012) Development and acceptability of a novel milk-free soybean-maizesorghum ready-to-use therapeutic food (SMS-RUTF) based on industrial extrusion cooking process. Matern Child Nutr (Epublication ahead of print version).

13. Omueti O \& Morton IO (1996) Development, acceptability, nutritional and physical characteristics of protein improved Nigerian abari (maize meal) prepared from soya and maize flours. Int J Food Sci Nutr 47, 369-375.
14. Macharia-Mutie CW, Van de Wiel AM, Moreno-Londono AM et al. (2011) Sensory acceptability and factors predicting the consumption of grain amaranth in Kenya. Ecol Food Nutr 50, 375-392.

15. Mensa-Wilmot Y, Phillips RD \& Sefa-Dedeh S (2001) Acceptability of extrusion cooked cereal/legume weaning food supplements to Ghanaian mothers. Int J Food Sci Nutr 52, 83-90.

16. Adeyemi IA \& Soluade EO (1993) Development and quality evaluation of pawpaw-ogi. Plant Foods Hum Nutr 44, 213-220.

17. Adu-Afarwuah S, Lartey A, Zeilani M et al. (2011) Acceptability of lipid-based nutrient supplements (LNS) among Ghanaian infants and pregnant or lactating women. Matern Child Nutr 7, 344-356.

18. Bosman MJC \& Bouwer SC (2008) HIV-positive and HIVnegative consumers accept an instant soy maize porridge. Health SA Gesondheit (University of Johannesburg), 1 September; available at http://www.thefreelibrary.com/ HIV-positive + and + HIV-negative + consumers + accept + an + instant + soy + maize...-a0184644148

19. Corneli AL, Piwoz EG, Bentley ME et al. (2007) Involving communities in the design of clinical trial protocols: the BAN Study in Lilongwe, Malawi. Contemp Clin Trials 28, 59-67.

20. McClelland RS, Baeten JM, Overbaugh J et al. (2004) Micronutrient supplementation increases genital tract shedding of HIV-1 in women: results of a randomized trial. J Acquir Immune Defic Syndr 37, 1657-1663.

21. Range N, Changalucha J, Krarup H et al. (2006) The effect of multi-vitamin/mineral supplementation on mortality during treatment of pulmonary tuberculosis: a randomised two-by-two factorial trial in Mwanza, Tanzania. Br J Nutr 95, 762-770.

22. Semba RD, Kumwenda J, Zijlstra E et al. (2007) Micronutrient supplements and mortality of HIV-infected adults with pulmonary TB: a controlled clinical trial. Int J Tuberc Lung Dis 11, 854-859.

23. Kelly P, Katubulushi M, Todd J et al. (2008) Micronutrient supplementation has limited effects on intestinal infectious disease and mortality in a Zambian population of mixed HIV status: a cluster randomized trial. Am J Clin Nutr 88, $1010-1017$.

24. Villamor E, Mugusi F, Urassa W et al. (2008) A trial of the effect of micronutrient supplementation on treatment outcome, T cells counts, morbidity, and mortality in adults with pulmonary tuberculosis. J Infect Dis 197, 1499-1505.

25. Jiamton S, Pepin J, Suttent R et al. (2003) A randomized trial of the impact of multiple micronutrient supplementation on mortality among HIV-infected individuals living in Bangkok. AIDS 17, 2461-2469.

26. Jefferds ME, Ogange L, Owuor M et al. (2010) Formative research exploring acceptability, utilization, and promotion in order to develop a micronutrient powder (Sprinkles) intervention among Luo families in western Kenya. Food Nutr Bull 31, 2 Suppl., S179-S185. 